Acta vet. scand. $1977,18,569-571$.

Brief Communication

\title{
MICROBIAL, IMMUNOLOGICAL AND TOXICOLOGICAL ASPECTS OF CANINE PYOMETRA*
}

There is agreement that uterine infection is necessary for the development of the varied picture of clinical pyometra which includes changes in the kidneys and other organs (Børresen 1975). Some important clinical manifestations of the pyometra syndrome have been explained in terms of an endotoxinaemia (Åsheim 1964, Schalm 1965).

The aim of the present investigation was to estimate the frequency of E. coli infected pyometras as opposed to other microbial pyometra infections in the Oslo region, to perform a quantitative examination of circulating agglutinating antibodies against the specific E. coli isolated from each individual uterus and to detect possible circulating bacterial endotoxins in serum.

\section{Materials and methods}

Eighty-three unselected pyometra patients admitted to the Department of Obstetrics, The Veterinary College of Norway, are included in the investigation. During surgery, the pyometra pus was aspirated into a syringe and isolation of microorganisms was performed. A pre-operative venous blood sample for the collection of serum was taken from 58 pyometra patients and from 21 healthy dogs.

The preparation of antigens of bacteria was done according to Krogstad (1974).

The agglutination test was performed on sera from dogs with growth of E. coli from uterus and on 15 control sera. The Widalagglutination test on inactivated sera was carried out according to Krogstad.

The Limulus amebocyte lysate test ${ }^{\star \star}$ was used for demonstration of endotoxin in serum, and the elimination of endotoxininhibiting substances in serum on this test was performed according to Moravek et al. (1974).

* This work has been supported by the Norwegian Research Council for Science and the Humanities.

* * Mallinckrodt Chemical Works, St. Louis, Mo., USA. 
Results and comments

Bacteriology. Hemolytic or non-hemolytic Escherichia coli was isolated from the uteri of $86 \%$ of the pyometra patients. Only 1 pus sample out of 83 showed no microbial growth, and from the remaining cases either $\beta$-hemolytic streptococci, Klebsiella, Proteus vulgaris, Staphylococcus aureus or Micrococcus sp. was isolated.

The predominance of $\mathbf{E}$. coli in pyometra is in accordance with findings in other countries (Grindlay et al. 1973, Sandholm et al. 1975).

Immunology. Homologous reaction titres using the Widaltest on sera from 25 pyometra patients were usually of the order of $1: 80$ while a titer of $1: 320$ was demonstrated in 1 case. Two sera showed no agglutination against either corresponding or other E. coli antigens. One of these was the only dog known to have been treated with large doses of cortisone.

There seemed to be only limited cross reactions between different sera and non-homologous E. coli strains, and when these occurred, the titres were relatively low, usually not exceeding $1: 20$. These results indicate the occurrence of several serologically different types of E. coli in canine pyometra. Eleven unselected E. coli pyometra strains were tested for agglutination with sera from 15 clinically healthy dogs of which only 2 gave agglutination with E. coli (titres of $1: 20$ ).

Detection of endotoxins in serum. Thirthy-three sera from pyometra dogs, 26 with E. coli, 4 with Streptococcus group L, 2 with Proteus vulgaris and 1 negative were examined for content of endotoxins with the Limulus amebocyte lysate test. None of the undiluted sera showed positive endotoxin reaction and only 4 sera in dilution 1:40 showed positive reaction. Two of these were from the cases where Proteus vulgaris was isolated, the remaining 2 from dogs where hemolytic E. coli was isolated. None of the 21 control sera showed positive endotoxin reactions. The method for the detection of circulating endotoxins seems to have been used diagnostically only in the human clinic. Several factors may influence endotoxin testing in dogs. The liver is active in clearing immune complexes from the circulation (Sandholm et al.) and thus may act as an endotoxin filter (Rutenburg et al. 1967). The serum endotoxin inhibitors seem to be of particular importance and appear to be most thoroughly studied in 
man (Moravek et al.). No reports on these substances in dog sera have been found although several experiments indicate definite species differences in the various responses to experimental endotoxin challenge (Hinshaw 1971). Thus there may be quantitative as well as qualitative differences in inhibitor effects between canine and human sera.

\section{Bergljot Børresen}

The Department of Obstetrics,

Veterinary College of Norway, Oslo and

Bjфrn Næess

The Department of Microbiology and Immunology,

Veterinary College of Norway and

The Norwegian Defence Microbiological Laboratory, Oslo.

\section{REFERENCES}

B $\phi r r e s e n, B .:$ Pyometra in the dog - A pathophysiological investigation. I. The pyometra syndrome, a review. Nord. Vet.-Med. 1975, 27, 508-517.

Grindlay, M., J. P. Renton \& D. H. Ramsay: O-groups of Escherichia coli associated with canine pyometra. Res. Vet. Sci. 1973, 14, $75-77$.

Hinshaw, L. B.: Release of vasoactive agents and the vascular effects of endotoxin. In Microbial Toxins. Vol. 5. S. Kadis, G. Weinbaum and S. J. Ajl, eds., Acad. Press, New York 1971, 209-260.

Krogstad, O.: Yersinia enterocolitica infection in goat. A serological and bacteriological investigation. Acta vet. scand. 1974, 15, 597608.

Moravek, J., Z. Konikova, J. Sedlak \& V. Matejicek: Detection of endotoxin in human plasma. J. Hyg. Epidem. (Praha) 1974, 18, 462464.

Rutenburg, S., R. Skarnes, C. Palmerio \& J. Fine: Detoxification of endotoxin by perfusion of liver and spleen. Proc. Soc. exp. Biol. (N. Y.) 1967, 125, 455-459.

Sandholm, M., H. Vasenius \& A.-K. Kivist $\emptyset$ : Pathogenesis of canine pyometra. J. Amer. vet. med. Ass. 1975, 167, 1006-1010.

Schalm, O. W.: Pyometra in the dog. Degenerative left shift in pyometra. In Schalm, O. W.: Veterinary Hematology. 2nd Ed. Lea \& Febiger, Philadelphia 1965, 559-560.

Asheim, $\breve{A} .:$ Renal function in dogs with pyometra. 8. Uterine infection and the pathogenesis of the renal dysfunction. Acta path. microbiol. scand. 1964, 60, 99-107.

(Received October 31, 1977).

Reprints may be requested from: Bergljot Børresen, The Veterinary College of Norway, P. O. Box 8146, Oslo Dep., Oslo 1, Norway. 